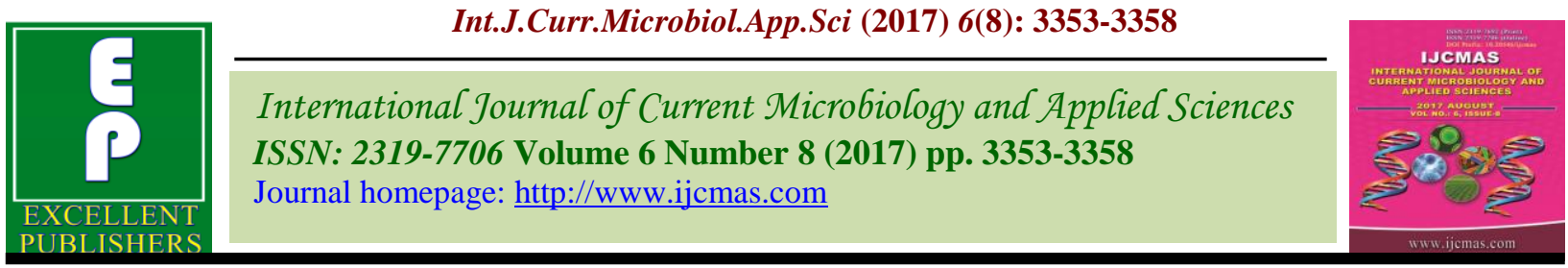

Original Research Article

https://doi.org/10.20546/ijcmas.2017.608.400

\title{
Genetic Variability Studies for Quantitative Traits of Restorer (R) Lines in Pearl Millet [Pennisetum glaucum (L.) R. Br.]
}

\author{
P.S. Basavaraj*, B.D. Biradar and G.M. Sajjanar \\ College of Agriculture RARS, Vijayapur, UAS Dharawd, Karnataka, India \\ *Corresponding author
}

\begin{tabular}{|c|c|}
\hline \multicolumn{2}{|r|}{ A B S T R A C T } \\
\hline & \multirow{6}{*}{$\begin{array}{l}\text { The present investigation was carried out at Regional Agricultural Research Station, } \\
\text { Vijayapur, Karnataka with } 75 \text { restorer (R) lines of pearl millet in a randomized block } \\
\text { design with two replications to estimate the genetic variability, heritability and genetic } \\
\text { advance for nine quantitative traits. Analysis of variance revealed significant differences } \\
\text { among the genotypes for all the traits studied indicating the presence of sufficient } \\
\text { variability in the studied material. The PCV was higher than GCV and the difference } \\
\text { between PCV and GCV was narrow for most of the characters revealing little influence of } \\
\text { the environment in the expression of these traits. High magnitude of GCV and PCV were } \\
\text { observed for traits like panicle weight ( } 24.71 \text { and } 25.57) \text {, stover weight per plot ( } 30.35 \text { and } \\
35.12) \text { and grain yield per plot ( } 21.93 \text { and } 26.78) \text { respectively. Suggesting the existence of } \\
\text { wide range of genetic variability in the germplasm for these traits and thus the scope for } \\
\text { improvement of these characters through simple selection would be better. High } \\
\text { heritability coupled with high genetic advance as per cent of mean was observed for } \\
\text { characters viz., panicle girth, panicle weight and stover weight per plot, grain yield per plot } \\
\text { and } 1000 \text { seed weight and indicating predominance of additive gene action for these } \\
\text { characters. Hence, Simple selection based on phenotypic performance of these characters } \\
\text { would be more effective. }\end{array}$} \\
\hline Keywords & \\
\hline $\begin{array}{l}\text { Pearl millet, } \\
\text { Variability, } \\
\text { Heritability, } \\
\text { Genetic advance. }\end{array}$ & \\
\hline Article Info & \\
\hline $\begin{array}{l}\text { Accepted: } \\
\text { 26 June } 2017 \\
\text { Available Online: } \\
10 \text { August } 2017\end{array}$ & \\
\hline & \\
\hline
\end{tabular}

\section{Introduction}

Pearl millet [Pennisetum glaucum (L.) R. Br.] is an important coarse cereal grown for food, feed and fodder in the arid and semi-arid regions of Sub-Sahara Africa, South Asia, mainly India and in north and south America.

It provides nutritionally superior and staple food for millions of people living in harsh environments characterized by erratic rainfall and nutrient-poor soil. Infact, pearl millet is the only suitable and efficient crop for arid and semiarid conditions because of its efficient utilization of soil moisture and higher level of heat tolerance than sorghum and maize.
Farmers prefer the crop as low cost, low risk option not only by choice but also by necessity (Harinarayana, 1987).

The grain yield is a complex character and direct selection for yield is not so much easy. Therefore, improvement in grain yield is made through improvement in contributing characters such as number of tillers/plant, panicle length, panicle girth, number of grains/panicle, 1000-grain weight, etc. along with yield (Arya et al., 2009). In order to have appropriate choice of characters for selection of desirable genotypes under planned breeding programme for yield enhancement, 
the knowledge of nature and magnitude of variability existing in available breeding material

The progress of selection in a population depended on the nature and magnitude of the variability. The estimates of variability of yield and yield contributing characters and their heritable components in the materials are more important in any crop improvement programme. Heritability in conjunction with genetic advance has a greater role to play in determining the effectiveness of selection of a character. Hence, in the present investigation 75 restorer ( $\mathrm{R}$ lines) were subjected to estimate the variability, heritability and expected genetic advance for different quantitative characters.

\section{Materials and Methods}

Experimental material consist of 75 diverse restorer (R) lines received from ICRISAT, Patencheru and were sown in RBD with two replication at Regional Agricultural Research Station, Vijayapur (Karnataka, India).

The recommended packages of practices were followed to raise the crop. Each germplasm line was sown in two rows of $4 \mathrm{~m}$. length with $45 \mathrm{X} 15 \mathrm{~cm}$ spacing. The observation on days to $50 \%$ flowering, plant height $(\mathrm{cm})$, panicle length $(\mathrm{cm})$, panicle girth $(\mathrm{cm})$, panicle weight (g/panicle), grain yield/plot $(\mathrm{kg})$, stover yield/plot $(\mathrm{kg})$, number of productive tillers (No.'s) and 1000 seed weight (g) were recorded on five randomly selected plants for all the lines in each replication. The phenotypic and genotypic coefficients of variations were computed as suggested by Burton and Devane (1953).

Genotypic coefficient of variation $(\mathrm{GCV})=\frac{\sigma^{2}{ }_{\mathrm{g}}}{\overline{\mathrm{X}}} \times 100$

Phenotypic coefficient of variation $(\mathrm{PCV})=\frac{\sigma^{2}{ }_{\mathrm{p}}}{\overline{\mathrm{X}}} \times 100$
Where,

$\sigma_{\mathrm{g}}^{2}=$ Genotypic variance, ${ }_{\mathrm{p}}^{2}=$ Phenotypic variance, $\bar{X}=$ General mean of the character

PCV and GCV values were categorized as low, moderate and high values as indicated by Sivasubramanian and Menon (1973) as follows.

0 -10 per cent: Low

10 - 20per cent: Moderate

$>$ 20: High

Heritability in broad sense was estimated as the ratio of genotypic variance to the phenotypic variance and expressed in percentage (Hanson et al., 1956).

Heritability $\left(\mathrm{h}^{2}\right)=\frac{\mathrm{Vg}}{\mathrm{Vp}_{\mathrm{p}}} \times 100$

Where, $\mathrm{Vg}=$ Genotypic variance, $\mathrm{Vp}=$ Phenotypic variance

The heritability percentage was categorized as low, moderate and high as followed by Robinson et al., (1949), as follows.

$0-30$ per cent: Low

$30-60$ per cent: Moderate

$>60$ per cent: High

\section{Genetic advance}

The extent of genetic advance to be expected by selecting five per cent of the superior progeny was calculated by using the following formula given by Robinson et al., (1949).

$\mathrm{GA}=\mathrm{i} \sigma_{\mathrm{p}} \mathrm{h}^{2}$

Where,

$\mathrm{i}=$ efficacy of selection which is 2.06 at 5 per cent selection intensity 
$\sigma_{\mathrm{p}}=$ phenotypic standard deviation, $\mathrm{h}^{2}=$ heritability in broad sense.

\section{Genetic advance as per cent of mean}

GA as per cent of mean $=(\mathrm{GA} / \bar{X}) \times 100$

Where, GA = genetic advance, $\bar{X}=$ general mean of character

The GA as per cent of mean was categorized as low, moderate and high as following by Johnson et al., (1955) as follows.

0 - 10 per cent : Low

10 - 20per cent: Moderate

20 and above: High

\section{Results and Discussion}

Analysis of variance for the experiment involving 75 pearl millet restorer lines for 9 quantitative characters revealed that the mean sum of squares were highly significant for all the traits studied, indicating presence of significant variability in the genotypes which can be exploited through selection (Table 1).

The extent of variability with respect to 9 characters in different genotypes measured in terms of mean, range, genotypic coefficient of variation (GCV), phenotypic coefficient of variation (PCV) along with the amount of heritability (h), expected genetic advance and genetic advance as per cent of mean (GAM) are presented in table 2 .

The phenotypic coefficient of variation (PCV) in general was higher than genotypic coefficient of variation (GCV) for most of the characters studied indicated the influence of environment on the manifestation of these characters. However, the difference between PCV and GCV was less for the characters, panicle weight, stover weight and grain yield per plot indicated low environmental influence and predominance of genetic factors controlling variability in these traits.

Table.1 Analysis of variance for quantitative characters in 75 restorer $(\mathrm{R})$ lines of pearl millet

\begin{tabular}{|c|l|c|c|c|}
\hline Sl. No. & \multicolumn{1}{|c|}{ Character } & $\begin{array}{c}\text { Mean sum of squares } \\
\text { Replications }\end{array}$ & Genotypes & Error \\
\hline 1 & Days to 50 per cent flowering & 15.36 & $18.28^{* *}$ & 9.30 \\
\hline 2 & Plant height (cm) & 379.42 & $517.93^{* *}$ & 133.08 \\
\hline 3 & Panicle length (cm) & 3.87 & $18.20^{* *}$ & 6.17 \\
\hline 4 & Panicle girth (cm) & 0.71 & $5.18^{* *}$ & 0.41 \\
\hline 5 & Panicle weight (g/panicle) & 0.01 & $175.83^{* *}$ & 5.66 \\
\hline 6 & Stover weight per plot (kg) & 0.99 & $1.09^{* *}$ & 0.15 \\
\hline 7 & Grain yield per plot (kg) & 0.05 & $0.23^{* *}$ & 0.04 \\
\hline 8 & 1000-grain weight (g) & 4.16 & $5.38^{* *}$ & 0.86 \\
\hline 9 & Number of productive tillers & 0.04 & $0.25^{* *}$ & 0.18 \\
\hline
\end{tabular}

Note: * Indicates significance at 5\% probability level.

** Indicates significance at $1 \%$ probability level 
Table.2 Estimates of genetic variability parameters for productivity traits in pearl millet restorer (R) lines

\begin{tabular}{|c|c|c|c|c|c|c|c|c|c|c|c|}
\hline \multirow{2}{*}{$\begin{array}{c}\text { Sl. } \\
\text { No. }\end{array}$} & \multirow{2}{*}{ Character } & \multirow{2}{*}{ Mean } & \multicolumn{2}{|c|}{ Range } & \multirow{2}{*}{$\sigma^{2} p$} & \multirow{2}{*}{$\sigma^{2} g$} & \multirow{2}{*}{ GCV $(\%)$} & \multirow{2}{*}{$\operatorname{PCV}(\%)$} & \multirow{2}{*}{$h_{b s}^{2}(\%)$} & \multirow{2}{*}{ GA } & \multirow{2}{*}{ GAM } \\
\hline & & & Min & Max & & & & & & & \\
\hline 1 & $\begin{array}{l}\text { Days to } 50 \text { per cent } \\
\text { flowering }\end{array}$ & 46.66 & 39 & 57 & 13.97 & 4.49 & 4.54 & 7.96 & 32.6 & 2.49 & 5.33 \\
\hline 2 & Plant height $(\mathrm{cm})$ & 133.10 & 62.50 & 151.3 & 256.25 & 123.17 & 8.33 & 12.02 & 48.1 & 15.85 & 11.90 \\
\hline 3 & Panicle length $(\mathrm{cm})$ & 24.85 & 16.4 & 28.6 & 12.18 & 6.01 & 9.86 & 14.04 & 49.3 & 3.54 & 14.27 \\
\hline 4 & Panicle girth $(\mathrm{cm})$ & 9.16 & 7.74 & 11.01 & 2.80 & 2.38 & 16.85 & 18.27 & 85.1 & 2.93 & 32.04 \\
\hline 5 & Panicle weight (g/panicle) & 37.32 & 18.00 & 52.25 & 90.75 & 85.08 & 24.71 & 25.57 & 93.8 & 18.39 & 49.29 \\
\hline 6 & Stover weight per plot $(\mathrm{kg})$ & 2.25 & 0.70 & 3.1 & 0.62 & 0.46 & 30.35 & 35.12 & 74.7 & 1.21 & 54.05 \\
\hline 7 & Grain yield per plot $(\mathrm{kg})$ & 1.40 & 0.90 & 2.0 & 0.14 & 0.09 & 21.93 & 26.78 & 67.0 & 0.51 & 36.99 \\
\hline 8 & 1000-seed weight $(\mathrm{g})$ & 11.76 & 9 & 14 & 3.12 & 2.25 & 12.76 & 15.02 & 72.2 & 2.62 & 22.34 \\
\hline 9 & Number of productive tillers & 1.61 & 1.38 & 3.4 & 0.22 & 0.03 & 11.94 & 29.28 & 16.6 & 0.16 & 10.04 \\
\hline
\end{tabular}


The amount of genetic variation considered alone will not be of much use to the breeder unless supplemented with the information on heritability estimate, which gives a measure of the heritable portion of the total variation. It has been suggested by Burton and Devane (1953) that the GCV along with heritability estimate could provide a better picture of the amount of advance to be expected by phenotypic selection. Since genetic advance is dependent on phenotypic variability and heritability in addition to selection intensity, the heritability estimates in conjunction with genetic advance will be more effective and reliable in predicting the response to selection (Johnson et al., 1955). Heritability in broad sense includes both additive and non-additive gene effects (Hanson et al., 1956). While, narrow sense heritability includes only additive components (Johnson et al., 1955). In the present study, heritability in broad sense was estimated. Highest broad sense heritability was recorded in the case of panicle girth, panicle weight, and stover weight per plant, grain yield per plot and 1000 seed weight. The study clearly showed that there is ample scope to improve these traits through selection.

Heritability estimates along with genetic advance are normally more helpful in predicting the gain under selection than heritability estimates alone (Johnson et al., 1955). High heritability accompanied with high genetic advance as percent of mean was recorded for panicle girth, panicle weight, stover weight per plot and grain yield per plot indicating the predominance of additive gene action and hence direct phenotypic selection is useful with respect to these traits. These results are in line with results of earlier works of Lakshmana et al., (2003). Sumathi et al., (2010), Vinodhana et al., (2013) and Kumar et al., (2014). The findings indicate that there exists adequate genotypic variation in the genotypes for per cent fruit set, number of fruits per plant, fruit diameter, average dry fruit weight, number of seeds per fruit and yield per plant showing high values of PCV, GCV and high heritability coupled with high genetic advance as per cent of mean suggesting predominance of additive gene action and lower influence of environmental factors in the expression of these traits with possibility for improvement through selection.

\section{References}

Aryana, K. J., Kulkarni, V. M., Desale, S. C. and Navale, P. A., 1996. Variability, heritability and genetic advance in pearl millet (Pennisetum glaucum (L.) R.Br.). Crop Res., 12: 399-402.

Burton, G.N., and Devane, E. M., 1953. Estimating heritability in tall fescue (Festuca arundiancea L.) from replicated clonal material. Agron. J., 45: 478-481.

Harinarayana, G., 1987. Pearl millet in Indian agriculture. "Proc. Int. pear millet workshop" ICRISAT, Pattencheru, Andra Pradesh. 5-17.

Johanson, H.W., Robinson, H. F. and Comstock, R. E., 1955. Estimates of genetic and environmental variability in Soyabean. Agron. J., 47(7): 314-315.

Kumar, R., Harish, S., Dalal, M. S., Malik, V., Devart, K., Chugh, P., Garg, and Raj, K., 2014. Studies on variability, correlation and path analysis in pearl millet [Pennisetum glaucum (L.) R. Br.] Genotypes. Forage Res., 40 (3): 163167.

Lakshmana, D., Surendra, P. and Gurumurthy, R., 2003. Genetic variability studies in pearl millet. Res. Crops. 4: 355-357.

Robinson, H. F., Comstock, R. F. and Harrey, P. H., 1949. Estimates of heritability and degree of dominance in corn. Agron. J., 41: 353-359.

Sivasubramanian, S., and Menon, M., 1973, 
Heterosis and inbreeding depression in rice. Madras Agril. J., 60: 1139.

Sumathi, P., Sumanth, M. and Veerabadhiran, P., 2010. Genetic variability for different biometrical traits in pearl millet genotypes (Pennisetum glaucum (L.) R.Br.). Electronic J. Pl. Breed., 1(4): 437-440.
Vinodhana, N., Sumati, P. and Satya, M., 2013. Genetic variability and interrelationship among morphoeconomic traits of pearl millet [Pennisetum glaucum (L.) R.Br.] And their implications in selection. Int. J. Plant, Anim. and Environ. Sci., 3: 145149.

\section{How to cite this article:}

Basavaraj, P.S., B.D. Biradar and Sajjanar, G.M. 2017. Genetic Variability Studies for Quantitative Traits of Restorer (R) Lines in Pearl Millet [Pennisetum glaucum (L.) R. Br.]. Int.J.Curr.Microbiol.App.Sci. 6(8): 3353-3358. doi: https://doi.org/10.20546/ijcmas.2017.608.400 